\title{
A systematic review of the role of Big Data Analytics in reducing the influ- ence of cognitive errors on the audit judgement
}

\author{
Fawad Ahmad \\ a) PhD Management Scholar, LUISS Guido Carli University, Rome, Italy
}

${ }^{a}$ Corresponding author.

E-mail address: fahmad@luiss.it

\section{A R T I C LE I N F O}

\section{Article history:}

Received 21 July 2018

Accepted 16 Jan 2019

Available online 1 July 2019

\section{JEL classification:}

M42

M52

Keywords

Memory

Judgement and decision-making

Cognitive errors

Auditing

Big Data Analytics

PRISMA methodology

\begin{abstract}
A B S T R A C T
This systematic literature review provides the association between memory processes, auditors judgement and decision-making process under the influence of cognitive errors. Due to limited cognitive resources, auditors are unable to analyze the population of accounting transactions, therefore, they use sampling and heuristics for information processing. In the context of Big Data (BD), auditors may face a similar problem of information overload and exhibit cognitive errors, resulting in the selection and analysis of irrelevant information cues. But Big Data analytics (BDA) can facilitate information processing and analysis of complex diverse Big Data by reducing the influence of auditor's cognitive errors. The current study adapts Ding et al., (2017) framework in the auditing context that identify causes of cognitive errors influencing auditor's information processing. This review identified 75 auditing related studies to elaborate the role of BD and BDA in improving audit judgement. In addition, role of memory, cognitive errors, and judgement and decision-making are highlighted by using 61 studies. The analysis provides useful insight in different open areas by proposing research propositions and research questions that can be explored by future research to gain extensive understanding on the association between memory and audit judgement in the context of $\mathrm{BD}$ and BDA.
\end{abstract}

(C)2019 ASEPUC. Published by EDITUM - Universidad de Murcia. This is an open access article under the CC BY-NC-ND license (http://creativecommons.org/licenses/by-nc-nd/4.0/).

Una revisión sistemática del papel del "Big Data Analytics" en la reducción de la influencia de los errores cognitivos en el juicio de auditoría

R E S U M EN

La revisión sistemática de la literatura proporciona la asociación entre los procesos de la memoria, el juicio de los auditores y el proceso de toma de decisiones bajo la influencia de errores cognitivos. Debido a los limitados recursos cognitivos, los auditores no pueden analizar la población de transacciones contables; por lo tanto, utilizan el muestreo y la heurística para el procesamiento de la información. En el contexto de Big Data (BD), los auditores pueden enfrentarse a un problema similar de sobrecarga de información y exhibir errores cognitivos, lo que resulta en la selección y análisis de indicios de información irrelevantes. No obstante, la analítica de Big Data (BDA) puede facilitar el procesamiento de información y el análisis de datos complejos y diversos al reducir la influencia de los errores cognitivos del auditor. El presente estudio adapta el marco de trabajo de Ding et al (2017) en el contexto de la auditoría que identifica las causas de los errores cognitivos que influyen en el procesamiento de la información del auditor. Esta revisión identificó 75 estudios relacionados con la auditoría para elaborar el papel de BD y BDA en la mejora del juicio de auditoría. Además, el papel de la memoria, los errores cognitivos y el juicio y la toma de decisiones se destacan mediante el uso de 61 estudios. El análisis proporciona una visión útil de los diferentes aspectos abiertos de la cuestión proponiendo propuestas y preguntas de estudio que puedan ser exploradas por la investigación futura para obtener una comprensión amplia de la asociación entre la memoria y el juicio de auditoría en el contexto de BD y BDA.

(C)2019 ASEPUC. Publicado por EDITUM - Universidad de Murcia. Este es un artículo Open Access bajo la licencia CC BY-NC-ND (http://creativecommons.org/licenses/by-nc-nd/4.0/). 


\section{Introduction}

The development of the information systems, communication technology and decreasing data storage cost facilitates the continuous real-time data collection, termed as "Big Data" (hereafter, BD) (Brown-Liburd, Issa and Lombardi, 2015). Typically, BD is a large population of different datasets consisting of both financial and non-financial data, with size challenging the storage capability and processing limits of traditional old business analytics (Earley, 2015; Gandomi and Haider, 2015; Manyika, Chui, Brown, Bughin, Dobbs, Roxburgh and Byers, 2016). BD has four key features i.e. high-volume, high-velocity, high-variety and uncertainveracity $^{1}$ (also known as 4Vs) (Zhang, Yang, and Appelbaum, 2015). The high-volume and high-velocity demands for more sophisticated, innovative and cost-efficient information systems to provide detailed insight of business, better risk assessment, competitive differentiation, quality, and effective judgement and decision-making (hereafter, JDM) (Gepp, Linnenluecke, O'Neill and Smith, 2018; Appelbaum, Kogan and Vasarhelyi, 2017). To respond these challenges in the field of auditing, big four auditing firms are investing in Big Data analytics capabilities (hereafter, BDA) (Alles, 2015; Gepp et al., 2018) and artificial intelligence (Appelbaum et al., 2017; Kokina and Davenport, 2017; Moffitt and Vasarhelyi, 2013) to improve the auditing process and provide unbiased audit judgement to clients. Recently, academics and scholars also shifted their focus on the application of BDA, which is evident from conferences and special issues by journals like American Accounting Association, Accounting Horizons, Critical Perspectives on Accounting on the use of BD and BDA. But, most of them emphasized the application of advanced data analytics on traditional transactions data (Alles and Gray, 2016) rather than on $\mathrm{BD}^{2}$.

BDA is a process to inspect, clean, transform, model, analyze, extract and communicate meaningful information that facilitates effective JDM (Cao, Chychyla and Stewart, 2015). $\mathrm{BD}$ is worthless in a vacuum and its potential value is unlocked by converting diverse complex data into meaningful audit evidence (Alles and Gray, 2016; Cao et al., 2015; Gandomi and Haider, 2015; Labrinidis and Jagadish, 2012). The use of BDA can improve the efficiency, effectiveness and quality of financial statement audit (Appelbaum, Kogan and Vasarhelyi, 2018; Cao et al.,2015) because of its successful application in different accounting and finance domains like financial distress modelling, financial fraud model and stock market prediction (Gepp et al., 2018). But auditing is still lacking behind in the application of BDA (Alles, 2015; Gepp et al., 2018). The big four auditing companies have begun to use BDA but still, its true applications are unknown and require extensive future research (Gepp et al., 2018). Schneider, Dai, Janvrin, Ajayi and Raschke (2015) predicts the extensive role of BDA in auditing and Earley (2015) acknowledges BDA as game-changer in the domain of auditing. It is important to note that analysis of BDA output is dependent on auditor's ability to handle BD and enhanced understanding of BDA (Huerta and Jensen, 2017) to analyze 100\% of transactions, identify unexpected trends and anomalies to

\footnotetext{
${ }^{1}$ High-volume refers to the abnormally large quantity of data, highvelocity refers to frequent changes in the data, high-variety refers to the collection of the diverse scope of data (i.e. both financial and non-financial data) and uncertain-veracity reflects the ambiguous integrity of data.

${ }^{2}$ Traditional accounting data has a limited scope and collected for specific period of time (Kogan, Alles, Vasarhelyi, and Wu, 2014), whereas, BD is continuous and its boundaries spans over both financial and non-financial data covering all aspects of inside and outside of the organization (Alles and Gray, 2016).
}

uncover fraudulent transactions (Earley, 2015). This can improve the quality of audit judgement and reduces the effect of auditor's lack of experience, knowledge and cognitive limitations. In these lines, one can argue that implementation of BDA to reduce the reliance over auditor's judgement in the selection of audit evidence to provide unbiased audit judgement.

The International Accounting Standard Board (IASB) provides a set of standards for auditors but still rely on auditor's professional judgement to select appropriate, sufficient and trustworthy audit evidence, termed as substance over form. It is important to note that how does relevance and trustworthiness of audit evidence be ensured when evidence selection depends on auditor's judgement. In addition, it is not humanly possible to analyze the population of information (Bonner, 2008) without sophisticated analytical tools. In the same lines, one can argue that BDA can provide value adding mechanism to ensure the quality, relevance, and trustworthiness of audit judgement. Furthermore, memory processes are a distinctive element of JDM (Birnberg and Shields, 1984; Kida, Smith and Maletta, 1998; Grossman and Welker, 2011) because of its role in the collection and analysis of new accounting information, and retrieval of relevant prior accounting information. While doing so, psychological limitations (e.g. emotions, mood, and sentiments) (Kahnmen and Tverskey, 1979) can inhibit auditor's information processing and JDM, resulting in the variation of audit quality across individual auditors (Gul, Wu and Yang, 2013). Therefore, it is important for auditors to identify and overcome the cognitive errors that can hinder information processing and JDM.

This systematic literature review aims at answering that what is the association between auditors memory processes and JDM, what are the main cognitive errors that auditors can exhibit during memory processes in the context of BD processing, how BDA can reduce the influence of cognitive errors on quality of audit judgement, and identify gaps in the form of research questions that can be explored by future studies to provide better understanding of constraining effect of cognitive errors on the association between auditors judgement and memory processes in the context of BDA.

The influence of memory processes on the accounting JDM process was established by Birnberg and Shields (1984). Recently, Ding, Hellmann and Mello (2017) provided the general framework in the context of both accounting and finance that integrates memory processes with JDM and identifies the cognitive errors that hinder the memory processes. Similarly, Alles and Gray (2016), Brown-Liburd et al., (2015) highlighted the main cognitive weakness that auditors can exhibit during the BD analysis. Brown-Liburd et al., (2015) highlighted four main cognitive weakness i.e. information overload, information relevance, pattern recognition, and ambiguity. Furthermore, Nelson and Tan (2005) provided a review of existing studies that used a psychological lens to understand, evaluate and analyze the auditing process (by using traditional accounting data). There is limited evidence of behavioral implications on the relationship between memory process and JDM in the context of BD and BDA in auditing. To fill this gap, the current study adapts the framework of Ding et al., (2017) in the context of auditing with the application of BD and BDA. The current study uses the PRISMA methodology to conduct a systematic literature review. This study contributes to the literature by providing a framework that linked memory process with JDM by stressing on the cognitive errors that can hinder the memory process and affect the quality of auditor's judgement. 
Table 1

List of journals and numbers of studies

\begin{tabular}{|c|c|}
\hline Journal title & $\begin{array}{c}\text { Number of selected } \\
\text { studies }\end{array}$ \\
\hline Accounting and Finance & 1 \\
\hline Accounting and Business Research & 1 \\
\hline Accounting Horizons & 5 \\
\hline Accounting review & 6 \\
\hline $\begin{array}{l}\text { Accounting, Auditing \& Accountability } \\
\text { Journal }\end{array}$ & 1 \\
\hline Accounting, organizations and Society & 13 \\
\hline $\begin{array}{l}\text { Advances in Accounting Behavioral } \\
\text { Research }\end{array}$ & 1 \\
\hline Auditing & 2 \\
\hline The Accounting Review & 3 \\
\hline Auditing: A Journal of Practice and Theory & 7 \\
\hline Behavioral Research in Accounting & 5 \\
\hline Contemporary Accounting Research & 1 \\
\hline Cost and Management & 1 \\
\hline $\begin{array}{l}\text { International Journal of Accounting } \\
\text { Information Systems }\end{array}$ & 3 \\
\hline International Journal of Auditing & 1 \\
\hline Journal of accounting and economics & 1 \\
\hline Journal of Accounting Education & 1 \\
\hline Journal of Accounting Literature & 2 \\
\hline Journal of Accounting Research & 7 \\
\hline $\begin{array}{l}\text { Journal of Accounting, Auditing and } \\
\text { Finance }\end{array}$ & 1 \\
\hline $\begin{array}{l}\text { Judgment and decision-making research in } \\
\text { accounting and auditing }\end{array}$ & 1 \\
\hline Managerial Auditing Journal & 1 \\
\hline Journal of Accounting Education & 1 \\
\hline Journal of Information Systems & 5 \\
\hline $\begin{array}{l}\text { Journal of Behavioral and Experimental } \\
\text { Finance }\end{array}$ & 2 \\
\hline Journal of Management Control & 1 \\
\hline $\begin{array}{l}\text { Journal of Emerging Technologies in } \\
\text { Accounting }\end{array}$ & 1 \\
\hline
\end{tabular}

\section{Methodology}

This review used PRISMA methodology (Moher et al., 2015) to conduct a systematic literature review to provide an association between memory processes and JDM under the influence of cognitive errors in the context of BD and BDA. The clear objectives of the study are identified which helped in the identification of theoretically relevant and similar studies to conduct the systematic review that resulted in new knowledge creation and coherent synthesis of existing research in the form of the framework (Hsieh and Shannon, 2005). The data collection and analysis can be divided into three stages: collecting relevant articles, studies filtering, and systematic literature review.

\section{Data collection}

In the first stage, articles with query ("Big Data" or "Big Data analytics" or "advanced analytics" or "audit judgement" and "memory" and "cognition" and "decision-making" or "heuristics" or "limitations" or "weakness" or "biases" or "errors") were searched in Web of Science. The total number of collected studies from the query was 1903 . Web of Science provided results of a query from all given subject categories. So, the first search results were refined to only "business finance" subject category and then from "source titles" accounting and behavioral related journals were selected, providing
Figure 1

Systematic review procedure

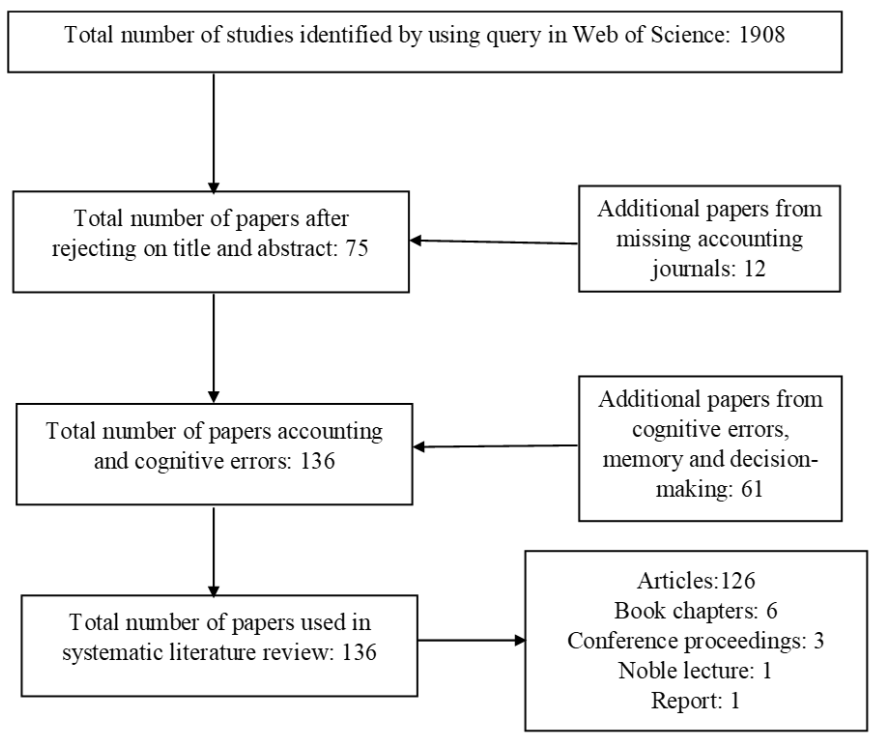

1903 studies. The list of selected journals is given in supplementary material. The Web of Science source titles does not provide studies from journals "Advances in Accounting Behavioral Research, Auditing, Behavioral Research in Accounting, Cost and Management, Judgment and decision-making research in accounting and auditing, International Journal of Auditing, and Journal of Accounting Literature". These journals are hand searched by using keywords "Big Data", "Big Data analytics", "advanced analytics", "memory", "cognition", "heuristics", "limitations", "weakness", "biases", "errors" and "audit judgement" in "Google Scholar".

\section{Studies screening}

The title and abstract of each study from Web of Science and google scholar was scanned and selected based on following two criteria: focus on the use of $\mathrm{BD}$ and/or BDA in the context of auditing and focus on the use of advanced analytics to improve audit judgment. It provided a total of 75 studies for the literature review. The table 1 provides list of accounting journals and numbers of studies selected for systematic review. As the objective of the study is to elaborate the role of cognitive errors while using BD and BDA in the auditing process, therefore, studies related to memory, decision-making and cognitive errors were hand searched by going through studies on JDM, memory and cognitive errors. In doing so, 61 studies were selected to elaborate the role of memory processes, cognitive errors and JDM. The selected studies were from psychological, cognitive sciences and decision sciences journals (e.g. Current directions in psychological science, Trends in cognitive sciences, Psychological Bulletin, Journal of Experimental Psychology-Learning Memory, Behavioral and Brain Sciences and Cognition, Decision Sciences).

\section{Data extraction for systematic literature review}

Finally, selected articles were reviewed with reference to the objectives of this systematic review. In total 136 articles were selected and used to get a deeper insight on objectives. Among them, 125 were published research papers, three art- 
Table 2

Articles used in the systematic review

\begin{tabular}{ll}
\hline Categories & Related articles \\
\hline Memory, cognitive & Arnold et al., 1980; Atkinson \& Shiffrin, 1968; Baddeley \& Hitch, 1977; Birnberg \& Shields, 1984; Blay, \\
limitations, JDM & 2005; Bless, 2000; Bower, 1992; Brainerd \& Reyna, 2002; Braun, 2000; Bruner et al.,1977; Buchanan \& \\
& Kock, 2001; Chang et al., 2002; Chewning, 1980; Choo, 1995; Cianci \& Bierstaker, 2009; Clore \& \\
& Huntsinger, 2007; Cowan, 2001; Criss et al., 2011; Danner et al., 2007; Dominique et al., 1998; Endler \& \\
& Magnusson, 1976; Estes, 1986; Fiske, 2013; Forgas, 1995; Gaudine \& Thome, 2001; Glover, 1997; \\
& Hastie \& Dawes 2010; Henckens et al., 2009; Hilton, 1980; Hirshlefier \& Teoh, 2003; Hoch, 1984; \\
& Hogarth \& Einhorn, 1992; Johansen et al., 2015; Jonides et al., 2008; Kahneman, 2002; Kahnmen \& \\
& Tverskey, 1979; Kida \& Smith, 1995; Kida et al., 1998; Kiken \& Fredrickson, 2017; Kruschke \& Johansen, \\
& 1999; Kuhlmann et al., 2005; Lampinen et al., 2006; Lerner et al., 2015; Libby \& Trotman, 1993; Libby \\
& et al., 2002; MacDonald, 1970; Maines, 1995; Mock \& Vasarhelyi, 1978; Moser, 1989; Neath \& Nairne, \\
& 1995; Norton, 1975; Reyna \& Brainerd, 1995; Ricciardi, 2008; Roediger \& Karpicke, 2006; Roediger \& \\
& Thorpe, 1978; Ruchkin et al., 2003; Schacter, 1999; Schick et al., 1990; Simon, 1978; Spilker \& Prawitt, \\
& 1977; Stahlberh \& Maass, 1977; Tomlinson et al., 2009; Tonoki \& Davis, 2012; Tversky \& Kahneman, \\
& 1973; Walinger \& Isaacowitz, 2006; Weber \& Johson, 2009; Wright \& Bower, 1992
\end{tabular}

Memory, cognitive limitations, JDM in accounting
Ahlawat, 1999; Alles \& Gray, 2016; Alles et al., 2006; Alles et al., 2008; Anderson et al.,1992; Asare, 1992; Ashton \& Ashton, 1988; Ashton, 1974; Ashton, 1990; Benbast \& Talyou, 1982; Bennett \& Hatfield, 2017; Bonner, 2008; Braun, 2000; Brown-Liburd et al. 2015; Chewning \& Harrell 1990; Choo, 1995; Driver \& Mock, 1975; Frederick, 1991; Gibbins, 1984; Glover, 1997 ; Green, 2008; Grossman \& Welker, 2011; Guiral-Contreras et al., 2007; Hackenbrack, 1992; Hellmann, 2016; Hogarth \& Einhorn, 1992; Iselin, 1988; Johnson, 1994; Kachelmeie \& Messier, 1990; Kida et al., 1998; Kleinmuntz, 1990; Kopp \& Bierstaker, 2006; Libby, 1985; Lowe \& Reckers, 1997; Messier et al., 2001; Miller \& Gordon, 1975; Moeckel, 1990; Morrill et al., 2012; Nelson \& Tan (2005); Nisbett et al., 1981; Pincus, 1989; Simnett, 1996; Smith \& Kida, 1991; Stocks \& Harrell, 1995; Tubbs et al., 1990; Weick, 1983; Whitecotton, 1996
Big Data and Big Data Analytics

Traditional data analytics
Alles \& Gray 2016; Alles, 2015; Appelbaum et al., 2017; Appelbaum et al.,2018; Brown-Liburd et al., 2015; Cao et al.,2015; Capriotti, 2014; Dowling \& Leech, 2007; Earley, 2015; Gandomi \& Haider 2015; Gepp et al., 2018; ; Huerta \& Jensen, 2017; Issa \& Kogan, 2014; Kogan et al., 2014; Labrinidis \& Jagadish, 2012; Manyika et al., 2016; Schneider et al., 2015; Zhang, et al., 2015

Amer, 2005; Chung et al., 2008; Courtis, 2004; Gul et al., 2013; So \& Smith, 2002; Tractinsky \& Meyer, 1999

Accounting and finance Ding et al., 2017; Gepp et al., 2018; Hellmann et al., 2017; Theis et al.,2012

Note: List of references used to make arguments in the systematic literature review

icles from conference proceedings, six books chapters, one noble lecture, and one report. In the systematic literature review, first abstract of each study is analyzed and later contents of each study are analyzed to gain deeper insight with reference to the objective of this review. In doing so, the main points from each study are noted and used in writing a systematic literature review. The systematic review highlighted the importance of BDA in reducing the effect of cognitive errors on audit judgment. The figure 1 provides an overview of systematic literature process. The selected articles are divided into five categories based on the arguments and findings used in each study. Table 2 provides five categories and related articles.

\section{Memory, JDM and cognitive errors}

Birnberg and Shields (1984) developed a framework to capture the effect of internal cognitive activities in the form of attention and memory on accounting decision-making. Their framework extended the decision-making models of Mock and Vasarhelyi (1978) and Hilton (1980) (based on Brunswik's lens model and decision theory), by incorporating the effect of cognitive processes. Birnberg and Shields (1984) framework were based on three memory stages i.e. attention, short-term memory, and long-term memory. According to their framework, attention paid to information cues to se- lect relevant information that is stored for a period spans over few milliseconds. In the second stage, selected information is encoded and stored in the short-term memory. Finally, the information is further encoded, rehearsed and stored in longterm memory for future retrieval.

Birnberg and Shields (1984) provided the role of cognitive activities in the decision-making process but they assumed that the decision-making process is highly efficient and does not account for any cognitive errors. However, literature posits that human JDM is significantly influenced by irrational factors like emotions, sentiments, and cognitive errors (Arnold, Sutton, Hayne and Smith, 1980; Chewning, 1990; Endler and Magnusson, 1976; Kahnmen and Tverskey, 1979; Spilker and Prawitt, 1977; Hirshlefier and Teoh, 2003; Ricciardi, 2008). For instance, studies have provided that the human brain has the limited attention and cognitive resources (Hirshlefier and Teoh, 2003), limiting the simultaneous processing of information and the human mind can only hold five to nine items of information in short-term memory (Cowan, 2010). Individuals are overloaded with information and must cross-check and reconfirm the evidence by retaining numerous chucks of information under a time constraint (Braun, 2000; Choo, 1995; Glover, 1997; Libby and Trotman, 1993). In the same lines, accountants and auditors face similar challenges in retrieving information from long- 
term memory during JDM process (Bonner, 2008; Hastie and Dawes, 2010; Libby and Trotman, 1993).

Recently, Ding et al., (2017) extended the Birnberg and Shields (1984) framework by suggesting that cognitive errors significantly distort JDM under the influence of cognitive limitations. Ding et al., (2017) framework consisted of two main levels: an association between memory processes and judgement, and cognitive errors exhibited during the information processing. They divided the judgement process into two groups: judgement without memory retrieval, and judgement with memory retrieval. The judgement without memory retrieval refers to instant judgement based on available information. However, judgement with memory retrieval considers the use of both available information extracted and information retrieved from long-term memory.

The current study adapts Ding et al., (2017) framework for a systematic literature review because it associates memory processes with JDM and also considers the influence of cognitive errors on memory processes. Ding et al., (2017) developed their framework in the context of accounting and finance but the focus of the current study is on the auditing process with reference to the application of BDA. Therefore, judgement with memory retrieval pathway is adapted because auditors make audit judgement based on both available information and past information. Even on the spot decisions and judgement requires auditors to make a professional judgement based on similar experience and knowledge.

\section{Memory, JDM and cognitive errors in the context of Big Data and Big Data analytics}

The recent debate on the role of $\mathrm{BD}$ in the auditing process highlights its importance in improving the quality, efficiency, and effectiveness of auditor's judgement (BrownLiburd et al., 2015). However, it is important for the auditors to identify and overcome cognitive errors to gain the advantage of BDA (Alles and Gray, 2016; Brown-Liburd et al., 2015). Auditors are trained to handle financial data and traditional business analytics output that require expertise to identify trends, patterns, correlation, anomalies and engaging in critical-thinking (Earley, 2015). This can be overcome by utilizing highly advanced analytics (Alles, 2015; Capriotti, 2014; Gepp et al., 2018), but still involves interpretation and analysis of output, completed by auditors (Alles, 2015; Earley, 2015).

Brown-Liburd et al., (2015), Hellmann (2016) and Nelson and Tan (2005) argued that auditors JDM is influenced by cultural factors, organizational factors, knowledge, expertise, professional commitment, heuristics, and cognitive errors. Specifically, errors like anchoring (belief adjustment), base-rate neglect, representativeness, overconfidence, input bias, calibration, sensitivity to base-rate, source credibility, dilution effect, and confirmatory bias influence auditor's judgement (Nelson and Tan, 2005; Smith and Kida, 1991). The framework presented in this study provides discussion on the cognitive errors exhibited by auditors during the auditing process in the context of BD and BDA. The framework is given in figure 2 consist of two levels: the association between memory processes and audit JDM, and the influence of cognitive errors on memory processes. The objective of the framework is to explore how memory processes select, analyze and interpret the output of BDA under the influence of cognitive errors. In addition, how cognitive errors through memory processes influence the quality, efficiency, and effectiveness of audit judgement.

\section{Causes of cognitive errors}

\section{Attention}

Attention is the first stage in the memory processes that allows auditors to analyze the information according to the specific auditing assertion. This step is important because auditors select relevant information from the BDA output. The auditing assertions stored in auditor's long-term memory are retrieved to carefully scan relevant information cues. Existing studies provide several cognitive errors that distort the attention maintainability of auditors, six important errors were selected that may have implications in the context of BDA.

\section{Selective attention}

Selective attention has a significant influence on auditors' ability to exhibit cognitive biases because of the limited processing capability and time constraint. Individuals have scarce cognitive resources (Hirshlefier and Teoh, 2003) and allocate selected attention to a specific set of activities (Weber and Johnson, 2009), termed as "conscious attention" (Simon, 1978). It is important to consciously identify the most relevant tasks to assign limited processing abilities (Kahneman, 2002). It helps individuals to ignore the distractions by consciously allocating cognitive resources to related activities. In addition, information encoding, and processing are affected by individual preference towards a specific set of information because of its distinct representation (salience effect). The salience effect can both facilitate or inhibit individual learning and information processing ability by allocating scarce resource to salient information (Fiske, 2013). Studies have suggested that information disclosure at different salient degrees influence the accounting user attention (Amer, 2005; Courtis, 2004; So and Smith, 2002; Tractinsky and Meyer, 1999). Furthermore, individuals stop searching for information once a satisficing solution has been found (Buchanan and Kock, 2001).

Accounting research on information overload suggests that high-volume of transaction information results in inefficient and suboptimal judgement (Alles, Brennan, Kogan and Vasarhelyi, 2006; Alles, Kogan and Vasarhelyi, 2008; BrownLiburd et al., 2015; Ashton, 1974; Chewning and Harrell, 1990; Driver and Mock, 1975; Miller and Gordon, 1975; Simnett, 1996; Stocks and Harrell, 1995). In addition, individual inability to extract relevant information cues from different information sources provides less favorable results than expected (Benbast and Talyou, 1982; Iselin, 1988; Kleinmuntz, 1990).

BDA analyze BD to provide output in organized and customized form (Labrinidis and Jagadish, 2012). BDA can overcome selective attention and information overload problem by providing the relevant information cues by analyzing the population of data, reducing the influence of salient effect and satisficing heuristics during information processing. This implies conscious allocation of scarce cognitive resources to most relevant information cues (Issa and Kogan, 2014) and quality audit evidence. Thus, the use of BDA in auditing process can help auditors to consciously select relevant information cues from data analytics output by reducing the influence of auditor's cognitive errors.

Proposition 1: Big Data Analytics facilitate auditor's conscious selection of relevant information cues (quality audit evidence). 


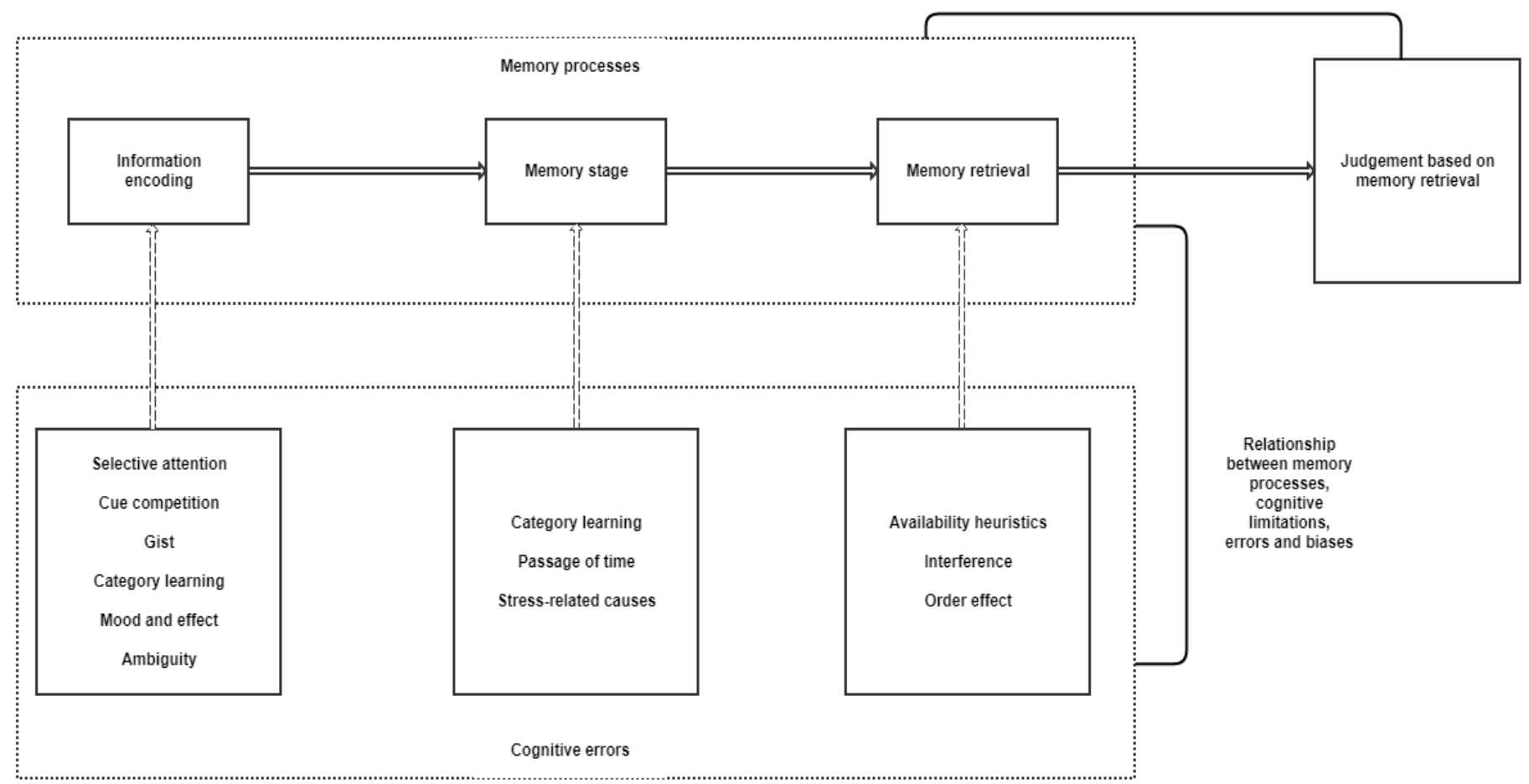

Note: Author adapted framework from Ding et al., (2017)

\section{Cue competition}

Decision makers exhibit tendency to prefer some cues relatively more than others (Ding et al., 2017), which results in higher attention to irrelevant information cues and negligence towards relevant cues (Blay, 2005; Kruschke and Johansen, 1999). However, auditors sometimes outperform the predetermined auditing checklist by preferring cues that are not mentioned in the checklist (Pincus, 1989), because of overconfidence in one's own abilities relatives to decision aids (Whitecotton, 1996). Such auditors demand diverse sets of information that surpass their processing abilities. Similarly, Schick, Gordin and Haka (1990) suggested that the cue competition is higher when auditors are faced with highvolume of information that exceeds their processing abilities, resulting in individual reliance over heuristics and unrelated information cues.

In addition, auditor's inability to disregard unrelated information cues (termed as dilution effect) results in the selection of unrelated information that can dilute the audit judgement quality (Nisbett, Zukier and Lemley, 1981; Hackenbrack, 1992). Furthermore, auditors can emphasize a specific set of information or sample size to achieve predesigned outcomes, resulting in "input bias". For instance, Kachelmeie and Messier (1990) and Messier, Kachelmeier and Jensen (2001) provided that auditors "work backward" to justify the desired sample size and auditors focused on efficiency prefer small samples relative to representative samples (Ashton, 1990), with a limited set of information.

Braun (2000) and Glover (1997) found that cue competition problem can be mitigated by implementing moderate time pressures on auditors. They argued that auditors following a specific pattern apply more conscious attention to the cue selection, properly analyze and select the task-related information cues, results in mitigation of cue competition. Similarly, experienced and knowledgeable auditors follow a more heuristic approach and justify unrelated information cues with reasoning based on their experience and knowledge. Whereas, novice auditors follow a more systematic approach by consciously analyzing and selecting the information cues that are directly related to the auditing assertion (Johnson, 1994).

BD is converted into organized and customized form of relevant information cues, preventing the dilution effect and input bias by analyzing the population of datasets. In addition, BDA provides the same output to both experienced and novice auditors, preventing heuristic behavior to ensure output based on relevant accounting assertions. This can ensure the systematic analysis and interpretation of information cues by experienced as well as novice auditors. Hence, the use of BDA in auditing process provides relevant information cues by excluding the noise to reduce cue-competition and facilitate the appropriate selection of information cues for analysis and interpretation.

Proposition 2: Big Data Analytics facilitates the selection of relevant information cues and prevent irrelevant information cues (noise).

\section{Gist}

Gist refers to a coding style that individuals use during the information processing (Ding et al., 2017). Individuals have limited cognitive resources (Hirshlefier and Teoh, 2003) and use different encoding strategies to efficiently and effectively analyze the available information. Under gist, individuals encode information according to its abstract meaning. For example: reading a paragraph based on its abstract idea. This 
phenomenon was explained by Reyna and Brainerd (1995) under the fuzzy-trace theory, which suggests that information coding is done by the individuals under events semantic features. Under time pressure gist provide an efficient strategy to analyze information by summarizing the essential meaning of information but does not involve exact information coding for future retrieval (Ding et al., 2017). Gist enables individuals to remember the main findings without quantitative figures and make them susceptible to cognitive errors (Chang, Yen and Duh, 2002). When individuals retrieve information, they can only relate to information as familiar or not and cannot recall a complete piece of information (Brainerd and Reyna, 2002; Lampinen, Watkins and Odegard, 2006), because information is encoded without precise quantitative data.

BDA provides abstract information cues by incorporating all relevant information specific to auditing assertion. This prevents the skimming of information cues for abstract meaning because BDA provides all relevant information in abstract and standardized format. In addition, auditors have a problem to recall the encoded abstract information, however, BDA output summaries are easily retrieval for future reference and data analytics automatically incorporates the historical as well as current information of clients to ensure a comprehensive analysis of related information (Brown-Liburd et al., 2015). Hence, BDA reduces the influence of gist information encoding by incorporating historical and current information in the analysis.

Proposition 3: Big Data Analytics overcome the influence of gist information encoding by incorporating relevant information (both historical and current) to provide abstract output to auditors to ensure the selection of quality audit evidence.

\section{Category learning}

Category learning is a type of cognitive process in which individual assigns concepts, task, objects, and events to different categories and explore new information with reference to predefined categories (Ding et al., 2017). Bruner et al., (1977) suggested that mental categories are set in mind to distinguish exemplars from non-exemplars to induce the learning process. With reference to auditing, category learning is closely related to how auditors encode the information cues and recall it when needed to compare with other related information cues.

Under time pressure and information overload, category learning provides an effective tool for quick encoding and analysis of information to extract meaningful information by relating to different categories of information. It reduces the time of information processing and provides means to efficiently and effectively improve the learning (Libby, Bloomfield and Nelson, 2002). However, inappropriate categorization can lead to cognitive errors. Auditors must carefully develop the mental categories and assign relevant information to each category because misleading categories and irrelevant information assignment result in cognitive errors. In BDA, data output is in the form of categories specific to auditing assertion that help auditors to select relevant audit evidence. For instance, Maines (1995) and Libby et al., (2002) found that the format of reports significantly influences the learning process and decision making of investors. Similarly, BDA output according to mental categories can improve the information processing and quality audit evidence.

Proposition 4: Big Data Analytics facilitate appropriate allocation of information to mental categories.

\section{Mood and affect}

The individual mood and affect also have a significant influence on JDM. Research has provided the impact of emotions, affect, mood and feelings on individual information processing and JDM (Bless, 2000; Bower, 1992; Clore and Huntsinger, 2007; Lerner, Li, Valdesolo and Kassam, 2015; Forgas, 1995; Kiken and Fredrickson, 2017; Wadlinger and Isaacowitz, 2006; Wright and Bower, 1992). For instance, Clore and Huntsinger (2007) concluded that mood significantly influences the judgement, good mood reflects positive judgement while bad mood translates into bad judgement. Kiken and Fredrickson (2017) argued that positive emotions means more than good moments and influence the social activities of the individual by encouraging them to invest for future well-being. Furthermore, Wright and Bower (1992) found that happy individuals are more optimistic whereas angry individuals are pessimistic about judgement. In terms of degree of riskiness and probabilities, individuals in good mood assign higher probabilities to good outcomes, while the bad mood is attributed towards lower probability outcomes. Similarly, Bless (2000) and Forgas (1995) found that positive and negative mood affects information processing, positive (negative) mood is attributed to heuristics (systematic) processing of information.

Gaudine and Thome (2001) provided a positive impact of mood on ethical decision-making. Cianci and Bierstaker (2009) found that negative mood induces relatively more positive performance. This suggests that individual in a negative mood are more careful in properly analyzing the financial performance. Furthermore, Chung, Cohen and Monroe (2008) analyzed the auditor's inventory valuation and concluded that auditors in positive mood assign the least conservative valuation to the inventory. However, auditors in negative mood allocate most conservative valuation to inventory. One can argue that different mood states possessed by decision-makers influence judgement in uncertain situations.

Literature also provides the effect of affective labelling assigned to information on the information coding process. For instance, Kida and Smith (1995) and Kida et al., (1998) examined the effect of affective labelling on decision makers information encoding and processing. They found that individuals associate affective responses with numerical information by comparing them with base values. Information encoded with affective responses are more effective and easier to retrieve. They further argued that affective response is a form of gist that is associated with information through conscious attention, which makes affective response part of encoded information.

In the context of BDA, the data output is provided to auditors but still, its analysis and interpretation are done by auditors. The mood and affective association of auditors with specific information cues may influence audit judgement. Auditors under the influence of mood and affect may exhibit cognitive errors and can select inappropriate audit evidence or can oversee relevant evidence, resulting in low-quality audit evidence and judgement.

Proposition 5: The negative (positive) mood and affective responses (no responses) associated with information encoding results into quality (low-quality), efficient (inefficient) and effective (ineffective) judgement.

\section{Ambiguity}

Ambiguity refers to the unstructured nature and variety of formats associated with data (Ding et al., 2017). BD is highly ambiguous because of the variety of data format, quantity 
and information resource reliability. BD provides several data analysis opportunities but also presents challenges like combining a different database of diverse nature, format and data type. The BDA solve this problem by converting different database format into a single format and provide output in a fixed format. Ambiguity intolerant individuals are more inclined towards reducing the level of uncertainty to focus on simple and clear situations. Therefore, irrelevant information is discounted to identify the solution (Lowe and Reckers, 1997). However, ambiguity-tolerant individuals are not annoyed by uncertainty and incorporate all information to get the solution (Norton, 1975). Ambiguity-intolerant individuals exhibit a high level of stress and can prematurely end decision-making process relative to ambiguity-tolerant (MacDonald, 1970).

The BDA helps auditors to reduce the ambiguity associated with diverse complex data by summarizing data into concise, standardized report format and facilitates the relevant selection of audit evidence. Furthermore, BDA overcomes the reservations of ambiguity-intolerant auditors by providing clear and concise reports for JDM. Thus, BDA reduces the ambiguity associated with diverse complex nature of $\mathrm{BD}$ by summarizing the diverse set of datasets into the standardized report, aiding the selection of quality audit evidence and quality JDM.

Proposition 6: Big Data Analytics reduces the ambiguity associated with the diverse and complex nature of Big Data by providing concise and standardized output to both Ambiguity tolerant and Ambiguity intolerant auditors to facilitated complete information analysis.

\section{Memory storage}

Memory storage refers to the storage of information in long-term memory after encoding for future retrieval (Ding et al., 2017). The cognitive errors of attention phase are carried over to memory storage. In this phase, the encoded information is first stored in short-term memory for short-period of time (i.e. 30 seconds), rehearsed, encoded and stored in long-term memory (Atkinson and Shiffrin, 1968; Birnberg and Shields, 1984; Ruchkin, Grafman, Cameron and Berndt, 2003). Memory storage is a "static" process and requires a significant brain and mental activities to store information in such form that it is easy to recall or retrieve (Weber and Johson, 2009). Three main cognitive limitations i.e. category storage, the passage of time and stress-related causes are identified as most relevant inhibitors during memory storage stage.

\section{Category storage}

Category learning is one of the main facilitators of cue selection and information processing. Information related to the mental categories are easy to process, encode and store (Estes, 1986). Furthermore, information encoded with reference to mental categories (auditing assertions) are efficiently and effectively stored in long-term memory and easy to retrieve. In addition, it also triggers the inference decisionmaking with reference to the label of category (refers to label special-mechanism hypothesis and the label super-salience hypothesis) (Johansen, Savage, Fouquet and Shanks, 2015). When information is encoded according to inappropriate categories than more mental and cognitive resources are required to rehearse the information for further encoding. Under time pressure and information overload, individual may not allocate the required cognitive resources to the rehearsal process, leading to cognitive errors and biases. Similarly, information stored without the reference of mental categories would require more time to rehearse and re-encode, therefore, both inappropriate information categorical encoding or without category encoding can increase the processing load on mental capabilities, resulting into cognitive errors and wrong encoding of information to different categories. This results in the decay of memory and incomplete encoding of information.

BDA output is provided with reference to pre-determined information categories. This facilitates auditors to efficiently and effectively encode and store information cues by relating mental categories with data analytics output. Additionally, it prevents the auditors to exhibit cognitive errors by mistakenly assigning different information cues to mental categories. Thus, preventing the wrong encoding and ensuring the relevant allocation of information cues to mental categories.

Proposition 7: Big Data Analytics provide output in categories according to specific auditing assertion that facilitates information storage, rehearsal and re-encoding according to auditor's mental categories.

\section{Passage of time}

In memory storage phase the main element is rehearsal or recall of encoded information because after the passage of time information starts to decay or forgotten. Memory decay theory suggests that events occurring during the information encoding and retrieval has no impact on stored memory, however, the time between information stored and retrieval may influence the quality of stored memory. Longer the passage of time after information encoding more will be memory decay.

Johnson (1994) conducted an experimental study to check the influence of time on auditor's memory retrieval ability. Auditors were assigned to review audit paper and respond to the questions in two passages of time, first after the first hour of reading the report and second after one day. The results suggested that auditors reporting responses after one hour have better recall capacity as compared to the auditors with responses after one day. This suggests that memory starts to decay or fades after one day, confirming the memory decay theory. Neuroscience also provides the confirmation of memory decay theory. Neath and Nairne (1995) and Tonoki and Davis (2012) used neurochemical to trace the decay of memory. They concluded that unless the memory is rehearsed or recalled it starts disintegrates and starts diminishing after one day.

BDA can solve this limitation by providing decision making aids to extract and analyze both previous and existing information of clients (Dowling and Leech, 2007), ensuring the analysis and interpretation of complex data without missing any information because of diminishing stored memory. The auditors can take assistance from numerous data mining feature of BDA to extract output based on both previous and current financial and non-financial data (Brown-Liburd et al., 2015) to improve the quality of audit JDM.

Proposition 8: Big Data Analytics can moderate the association between memory decay and quality of judgement by reducing the effort to retrieve information from memory rather providing it on demand to auditors. 


\section{Stress-related causes}

Stress is directly related to memory retrieval (Kuhlmann, Piel and Wolf, 2005) and impairment (Henckens, Hermans, Pu, Joëls and Fernández, 2009). Psychology research suggests that stress has a significant influence not only on memory retrieval but also on information processing and encoding (Dominique, Roozendaal and McGaugh, 1998; Kuhlmann et al., 2005). Under stress, decision makers are not able to pay attention to the stimulus, consequently not able to retrieve relevant information from memory. Similarly, under stress, the human body secretes stress hormones in the body and brain, which results in the impairment of long-term memory (Henckens et al., 2009).

In the context of auditing, there is a limited number of studies investigating the influence of stress on JDM. Few studies like Choo (1995), Bennett and Hatfield (2017) and Braun (2000) suggested that time stress significantly influence information processing, memory retrieval, and judgement making process. Similarly, Weick (1983) suggested that pressure from clients and superiors, the pressure between ethics and interest, anxiety over the consequences of bad judgment and relation with peers and clients influence individual memory.

BDA facilitates auditors by reducing the size and complexity of BD and provide summarize information cues for encoding and processing. This reduces the negative influence of time pressure by readily providing the information in the abstract form, which improves the quality of audit judgement. Because of anxiety and depression, auditors tend to forget information (it can be technical information, auditing assertion or client-related information) but BDA can prevent the mental stress because of manager fear and pressure that can affect the memory impairment by incorporating all relevant information in the output. Hence, reducing the level of stress in the auditors that can arise because of failure to recall relevant information cues stored in the memory, which can further result in cognitive errors.

Proposition 9: Big Data Analytics reduce the stress-related activities associated with memory retrieval by readily providing historical and current information.

\section{Memory retrieval}

The memory retrieval refers to the recollection of previously stored encoded information, but stored information is subject to distortion or errors (Stahlberh and Maass, 1977), resulting in the difference between stored and retrieved information. This gap is because of the incorporation of new encoded information and decay of previously stored information (Henckens et al., 2009; Jonides, Lewis, Nee, Lustig, Berman and Moore, 2008; Schacter, 1999). When memory is retrieved individual reconstruct the missing part of the information from other supplement information based on their personal experience (Ding et al., 2017). This distortion in the memory retrieval process is because of availability heuristics, interference, serial position effect, mood and affect and stress-related activities.

\section{Availability heuristics}

Availability heuristics refer to the information that comes most readily in the mind during problem-solving (Tversky and Kahneman, 1973). It suggests that the likelihood of judgement is associated with how readily similar information or scenarios are recalled that closely associate with the problem. Tversky and Kahneman (1973) argued that the information processing of the frequent event is mainly done by using availability heuristics as a shortcut decision-making strategy. The more instances in which the same information is recalled or ease with which certain instances are remembered, higher the probability of event occurrence judgement (Moser, 1989).

In the context of accounting, Libby (1985) suggested that individuals using availability heuristics are not able to recall a complete set of information because of quick encoding of information without quantitative data, which make individuals susceptible to inference biases. Furthermore, it also results in the wrong inference of event based on the biased representation of most readily available information. Additionally, experienced auditors exhibit more preference towards availability heuristics by extracting the meaning of new information cues with familiar, readily used stored information cues. Experienced auditors constantly retrieve the same information from memory and consider the application of the same information in all auditing assertions by linking different information cues based on biased supporting reasoning (Johnson, 1994). However, novice auditors properly analyze the information cues and retrieve relevant stored information after unbiased and systematic processing of stored information.

In BDA, the output consists of relevant information cues and auditors associate most used and preferred information cues (stored in memory and constantly recalled) to analyze and interpret the information. BDA can prevent the use of availability heuristics to by providing relevant information cues according to auditing assertion, but experienced and knowledgeable auditor can somehow relate stored information cues with new information cues through reasoning.

Proposition 10: Big Data Analytics output reduces the influence of availability heuristics by providing relevant abstract information.

\section{Interference}

Interference refers to memory loss because of the interaction of retrieval cues (old and new information cues) stored with similar traces in the memory (Criss, Malmberg and Shiffrin, 2011). Interference influence all stage of memory process, but it has a most significant influence on memory retrieval process. It influences memory in two ways i.e. retroactive interference and proactive intervention (Hoch, 1984). Retroactive interference deals with the memory retrieval and interaction between old and new memories, which results in distorting or diminishing of old memories and forgetfulness. Whereas, proactive intervention refers to the encoding of new information and how individuals react and encode when new information interferes with old information (Baddeley and Hitch, 1977). Specifically, interference influences the memory processing speed and memory retention ability of the individual in similar or conflicting information (Tomlinson, Huber, Rieth and Davelaar, 2009). Studies in psychology have confirmed the effect of interference in information processing by suggesting that there exists interference between previously stored information cues and newly encoded information cues, inhibiting memory rehearsal and retrieval of information (Roediger and Karpicke, 2006; Roediger and Thorpe, 1978). Furthermore, interference also affects the JDM process by generating the reasons based on previous information. Thus, inhibiting individuals to incorporate new information and continues to use the previous thinking process and provide new-reasoning based on previous information (Danner, Aarts and de Vries, 2007; Hoch, 1984). 
In auditing context, studies like Anderson, Kaplan and Reckers (1992), Frederick (1991), Green (2008), Kopp and Bierstaker (2006) and Morrill, Morrill and Kopp (2011) provided the influence of interference on judgement and reason generation. For instance, Morrill et al., (2011) investigated the role of sequences in evaluating client's internal control before or after risk assessment. Their findings suggest that auditors do not rely on memory retrieval from the internal control evaluation experience to provide a risk assessment. However, auditors risk assessment judgement was hindered by interference between internal control memory and risk assessment (Anderson et al., 1992; Frederick, 1991; Kopp and Bierstaker, 2006).

The most important implication of interference is to explain why more experienced and intelligent auditors exhibit cognitive errors in long-term memory retrieval (Johnson, 1994). They can relate information cues and reconstruct the memory based on their experience and knowledge, resulting in cognitive errors due to memory interference (Moeckel, 1990). Because of more sophisticated knowledge, experienced auditors can link unrelated memory fragments to generate reasons that support their judgement (Johnson, 1994). So, they put less effort into evaluating each fragment of information to generate reasons. Furthermore, experienced managers prefer those fragments of information that provide reasons confirming their judgement, which is also termed as "confirmation bias". However, novice auditors because of less experience put more effort to link accurate information fragments to retrieve a memory, resulting in more efficient and effective audit judgement. Because of less experience, auditors also reconfirm their judgement by repeated self-examination.

In the context of BDA, auditors are exposed to relevant information cues (data analytics output) with specific mental categories. Data analytics output is in abstract and standardized format, so it is according to mental categories of auditors. During encoding and memory storage standardized format can facilitate the information processing but during recall of information from stored memory interference between encoded information, which can result in the biased retrieval of information and can make auditors susceptible to cognitive errors. BDA can solve this problem by including both historical and new relevant information in the analysis. This can help auditors to relate and recall similar information from memory as given in data analytics output. Furthermore, it can also reduce the auditor's total reliance on stored memory but to use stored memory to confirm information. Similarly, relevant information in BDA output also reduces the chances of an irrelevant association of new information with stored information through reasoning by experienced auditors.

Proposition 11: Big Data Analytics can reduce the influence of interference between relatively new encoded information with old information by incorporating historical as well as new information in output, reducing the need for memory retrieval.

\section{Order effect}

The order effect refers to when people recall more proficiently last and first items as compared to middle items of information (Hogarth and Einhorn, 1992). The order effect is a combination of two effects i.e. primacy effect (probability to recall first items of information) and recency effect (likelihood to recall last items on the list). In accounting and finance, order effect has given considerable importance in analyzing information and retrieval of information during JDM (Hellmann, Yeow and Mello, 2017; Theis, Yankova and Eulerich,2012). Specifically, studies like Ahlawat (1999),
Table 3

Major findings, research propositions and research questions (part 1)

\begin{tabular}{|c|c|c|}
\hline Major findings & Propositions & $\begin{array}{l}\text { Research questions for } \\
\text { future research }\end{array}$ \\
\hline \multicolumn{3}{|c|}{ ATTENTION } \\
\hline \multicolumn{3}{|l|}{ Selective attention } \\
\hline $\begin{array}{l}\text { - Decision makers must allocate } \\
\text { scarce cognitive resources to } \\
\text { relevant tasks by avoiding } \\
\text { individual preferences to specific } \\
\text { information to improve quality } \\
\text { of JDM. } \\
\text { - Decision makers stop infor- } \\
\text { mation search when satisficing } \\
\text { solution has been found. } \\
\text { - Auditors must clearly } \\
\text { understand and consciously } \\
\text { select relevant information cues } \\
\text { from different sets of } \\
\text { information outputs. } \\
\text { - BDA help auditors to consciously } \\
\text { select relevant information cues } \\
\text { from data analytics output by } \\
\text { reducing the influence of } \\
\text { auditor's cognitive errors. } \\
\text { Cue competition }\end{array}$ & $\begin{array}{l}\text { Big Data Analytics } \\
\text { facilitate auditor's } \\
\text { conscious selection } \\
\text { of relevant } \\
\text { information cues } \\
\text { (quality audit } \\
\text { evidence). }\end{array}$ & $\begin{array}{l}\text { - What strategies do } \\
\text { auditors can use to select } \\
\text { and analyze information } \\
\text { cues from BDA output? } \\
\text { - How can represen-tation } \\
\text { of BDA output influence } \\
\text { the auditor information } \\
\text { selection process? } \\
\text { - How can BDA solve } \\
\text { auditor's attention } \\
\text { deficiency limitation? }\end{array}$ \\
\hline $\begin{array}{l}\text { Overconfident decision makers } \\
\text { demand more information and } \\
\text { pay more attention to familiar } \\
\text { information by diluting judge- } \\
\text { ment with irrelevant } \\
\text { information. } \\
\text { - Under time pressure auditor pay } \\
\text { more attention to con-sciously } \\
\text { selecting the relevant } \\
\text { information cues, resulting in } \\
\text { quality audit judgement. } \\
\text { - Novice auditors follow more } \\
\text { systematic approach by } \\
\text { consciously analyzing and } \\
\text { selecting the information cues } \\
\text { that are directly related to the } \\
\text { auditing assertion. } \\
\text { BDA provide relevant } \\
\text { information cues by excluding } \\
\text { the noise to reduce cue- } \\
\text { competition and facilitated the } \\
\text { appropriate selection of infor- } \\
\text { mation cues by reducing the } \\
\text { influence of cognitive errors. } \\
\text { Gist }\end{array}$ & $\begin{array}{l}\text { Big Data Analytics } \\
\text { facilitates the } \\
\text { selection of } \\
\text { relevant informa- } \\
\text { tion cues and } \\
\text { prevent irrelevant } \\
\text { information cues } \\
\text { (noise). }\end{array}$ & $\begin{array}{l}\text { - How auditor's cognitive } \\
\text { deficiency can be rectified } \\
\text { to disregard the } \\
\text { irrelevant information } \\
\text { cues and select relevant } \\
\text { information cues for } \\
\text { quality audit judgement? } \\
\text { - How time pressure } \\
\text { reduces the cognitive } \\
\text { deficiency of auditors to } \\
\text { consciously select the } \\
\text { relevant information cues } \\
\text { and how BDA can reduce } \\
\text { the influence of cognitive } \\
\text { deficiency? } \\
\text { - Is time pressure can be } \\
\text { used to eliminate the } \\
\text { dilution effect in auditing } \\
\text { under BD context? }\end{array}$ \\
\hline $\begin{array}{l}\text { Under time pressure gist helps } \\
\text { auditors to efficiently analyze } \\
\text { the information and provide } \\
\text { quality judgement but it } \\
\text { influences the future } \\
\text { information retravel by making } \\
\text { auditors susceptible to cognitive } \\
\text { errors and biases. } \\
\text { - BDA output in auditing process } \\
\text { prevent the influence of gist } \\
\text { information encoding by } \\
\text { incorporating all relevant } \\
\text { information that auditors may } \\
\text { require to make unbiased audit } \\
\text { judgement. }\end{array}$ & $\begin{array}{l}\text { Big Data Analytics } \\
\text { overcome the } \\
\text { influence of gist } \\
\text { information } \\
\text { encoding by incor- } \\
\text { porating relevant } \\
\text { information (both } \\
\text { historical and } \\
\text { current) to provide } \\
\text { abstract output to } \\
\text { auditors to ensure } \\
\text { the selection of } \\
\text { quality audit } \\
\text { evidence. }\end{array}$ & $\begin{array}{l}\text { - What strategies BDA } \\
\text { provide to auditors for } \\
\text { using gist but also to } \\
\text { facilitate the efficient } \\
\text { future memory retrieval? }\end{array}$ \\
\hline \multicolumn{3}{|l|}{ Category learning } \\
\hline $\begin{array}{l}\text { - Category learning facilitates the } \\
\text { information processing by } \\
\text { encoding the information with } \\
\text { reference to mental categories } \\
\text { and it also facilitates the } \\
\text { efficient memory retrieval and } \\
\text { learning. } \\
\text { - Encoding of information in } \\
\text { relevant mental categories } \\
\text { facilitates learning, however, } \\
\text { inappropriate information } \\
\text { encoding with reference to } \\
\text { mental categories leads to } \\
\text { cognitive errors and biases. } \\
\text { - Big Data analytics output } \\
\text { according to mental categories } \\
\text { can improve the information } \\
\text { processing of auditors and } \\
\text { quality audit evidence, resulting } \\
\text { in quality audit judgement. }\end{array}$ & $\begin{array}{l}\text { Big Data Analytics } \\
\text { facilitate ap- } \\
\text { propriate alloca- } \\
\text { tion of info- } \\
\text { rmation to mental } \\
\text { categories. }\end{array}$ & $\begin{array}{l}\text { - How mental categories } \\
\text { help the auditors to } \\
\text { develop knowledge } \\
\text { structure that can } \\
\text { facilitate the selection, } \\
\text { processing, encoding, } \\
\text { analysis and storage of } \\
\text { information cues? } \\
\text { - How can auditors build } \\
\text { mental categories with } \\
\text { reference to BDA output? } \\
\text { - How can auditors } \\
\text { efficiently and effectively } \\
\text { utilize category learning } \\
\text { for auditing by using BD? }\end{array}$ \\
\hline
\end{tabular}

Note: Author findings, propositions and directions for future research based on systematic literature review 
Asare (1992), Guiral-Contreras et al., (2007) and Tubbs, Messier and Knechel (1990) found that sequence of information processing influence the auditor JDM.

Auditing is a sequential process of obtaining, analyzing and evaluating audit evidence (Gibbins, 1984). In doing so, auditors constantly update their beliefs based on audit assertions by using sequential anchoring and adjustment process, which is also termed as "belief-adjustment model" (Hogarth and Einhorn, 1992). The model suggests that order of information is not relevant till the information is consistent (all positive or negative information). But when information is mixed, i.e. both positive and negative than recency effect will occur. Asare (1992), Ashton and Ashton (1988), GuiralContreras et al., (2007) and Tubbs et al., (1990) supported the prediction of the belief-adjustment model by suggesting that auditors exhibit recency effect in complex or mixed situations. Furthermore, Ahlawat (1999) investigated the group effect on the auditor's ability to exhibit a recency effect. The results suggested that auditors working in a group experienced less recency because group memory is more accurate, however, judgement of auditors working independently were inhibited by recency effect.

BDA output includes current and historically relevant information. Furthermore, data analytics incorporated data over the period and auditors can also retrieve the previous reports from the database. Thus, recency effect can be reduced by use of BDA and ensuring reconfirmation of information retrieved from memory with data analytics output.

Proposition 12: Big Data Analytics can reduce the auditor's ability to exhibit recency effect by incorporating all relevant information in data analytics output.

\section{Conclusion}

This study provided the association between memory processes and auditors judgement in the context of BD and BDA. Furthermore, it highlighted the cognitive errors exhibited by auditors during the auditing process. This study adapts Ding et al., (2017) framework in the context of auditing to provide an association between the memory process and audit judgement. The framework consists of two levels: the association between memory processes and audit JDM, and the influence of cognitive errors on memory processes. The objective of the framework is that how memory processes select, analyze and interpret the BDA output under the influence of cognitive errors. In addition, the current study discussed how cognitive errors exhibited by auditors directed through memory processes influence the quality, efficiency, and effectiveness of audit judgement. Furthermore, systematic review illustrates that BDA can help in overcome the cognitive errors exhibited by auditors by providing the complete list of relevant information cues, reducing the influence of auditor's cognitive limitations on audit judgement and ensuring the quality, efficiency, and effectiveness of audit judgement. In the end, research questions are identified for future studies to provide a better understanding of the use of BDA and its role in improving audit judgement by reducing the influence of auditor's cognitive errors.

Table 3 provides the list of research questions based on the proposition extracted from a systemic literature review. The list of research questions is not inclusive but provides the starting point for future research to study the influence of cognitive errors that inhibit auditor's judgement.

The framework in the study provides insight on cognitive limitations exhibited by auditors and the role of advanced BDA to improve the quality of audit judgement by reducing
Table 3

Major findings, research propositions and research questions (part 2)

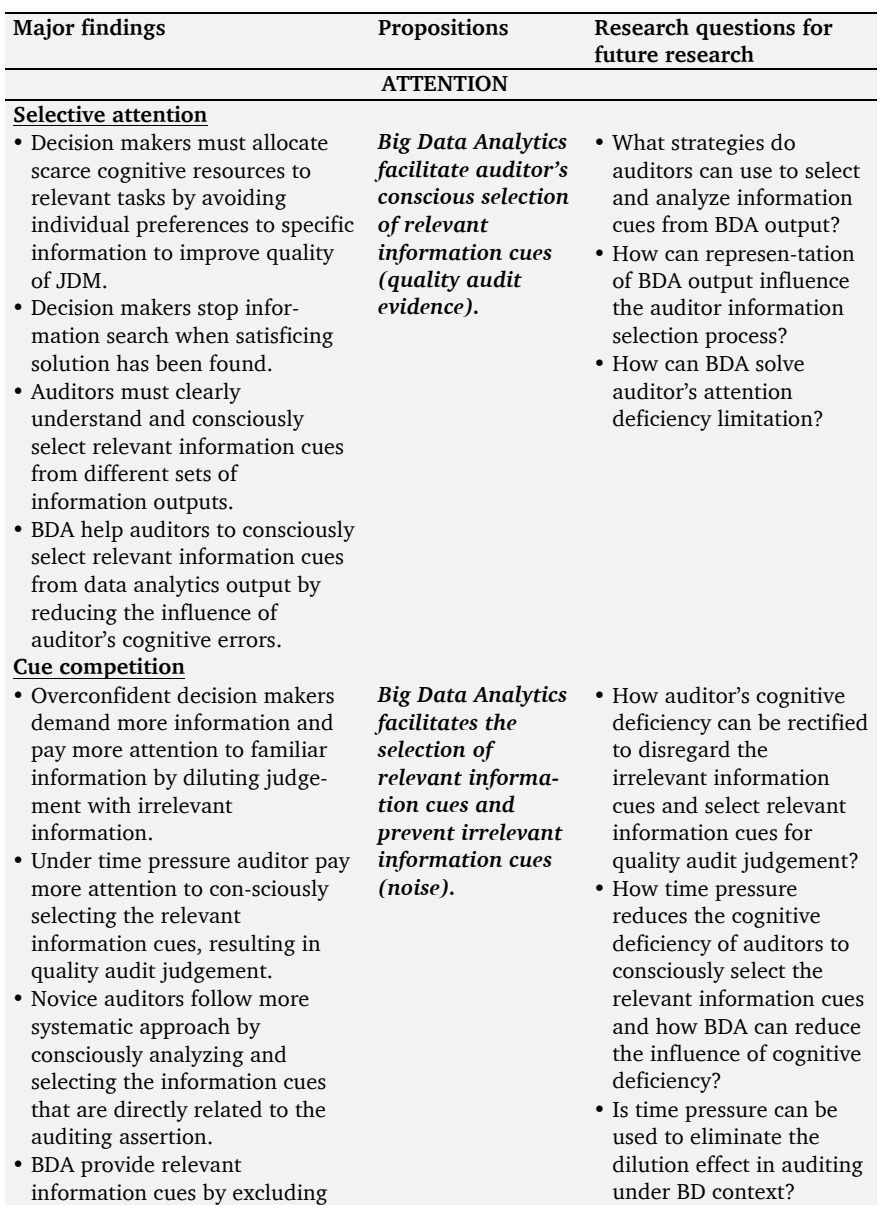

the noise to reduce cuecompetition and facilitated the appropriate selection of information cues by reducing the influence of cognitive errors. Gist

- Under time pressure gist helps auditors to efficiently analyze the information and provide quality judgement but it influences the future

information retravel by making auditors susceptible to cognitive errors and biases.

- BDA output in auditing process prevent the influence of gist information encoding by incorporating all relevant information that auditors may require to make unbiased audit judgement.

Category learning

- Category learning facilitates the information processing by encoding the information with reference to mental categories and it also facilitates the efficient memory retrieval and learning.

- Encoding of information in relevant mental categories facilitates learning, however, inappropriate information encoding with reference to mental categories leads to cognitive errors and biases.

- Big Data analytics output according to mental categories can improve the information processing of auditors and quality audit evidence, resulting in quality audit judgement.

Big Data Analytics overcome the influence of gist information encoding by incorporating relevant information (both historical and current) to provide abstract output to auditors to ensure the selection of quality audit evidence.

Big Data Analytics facilitate appropriate allocation of information to mental categories.

- What strategies BDA provide to auditors for using gist but also to facilitate the efficient future memory retrieval?

Note: Author findings, propositions and directions for future research based on systematic literature review
How mental categories help the auditors to wledge structure that can facilitate the selection, processing, encoding, analysis and storage of information cues?

- How can auditors build mental categories with reference to BDA output?

- How can auditors efficiently and effectively utilize category learning for auditing by using $\mathrm{BD}$ ? 
Table 3

Major findings, research propositions and research questions (part 3)

\begin{tabular}{|c|c|c|}
\hline \multicolumn{3}{|c|}{ MEMORY RETRIEVAL } \\
\hline Availability heuristics & & \\
\hline $\begin{array}{l}\text { The use of availability heuristics } \\
\text { results in cognitive errors, due to } \\
\text { lack of optimal statistical } \\
\text { judgement. }\end{array}$ & $\begin{array}{l}\text { Big Data Analytics } \\
\text { output reduces the } \\
\text { influence of } \\
\text { availability } \\
\text { heuristics by } \\
\text { providing relevant } \\
\text { abstract } \\
\text { information. }\end{array}$ & $\begin{array}{l}\text { - What strategy BDA can } \\
\text { adapt to prevent } \\
\text { availability heuristics } \\
\text { during audit judgement? }\end{array}$ \\
\hline \multicolumn{3}{|l|}{ Interference } \\
\hline $\begin{array}{l}\text { - Interference inhibits individual's } \\
\text { ability to incorporate new } \\
\text { information and continues to use } \\
\text { the previous thinking process and } \\
\text { provide new-reasoning based on } \\
\text { previous information. } \\
\text { - Auditors stored memory hinders } \\
\text { the reason generation for audit } \\
\text { generation based on the new } \\
\text { information. } \\
\text { - Experienced (novice) auditors } \\
\text { exhibit more (less) cognitive } \\
\text { errors because they can (cannot) } \\
\text { link the unrelated stored } \\
\text { information fragments to confirm } \\
\text { their predisposition audit } \\
\text { judgement, by following } \\
\text { heuristics information } \\
\text { processing. }\end{array}$ & $\begin{array}{l}\text { Big Data Analytics } \\
\text { can reduce the } \\
\text { influence of } \\
\text { interference } \\
\text { between relatively } \\
\text { new encoded } \\
\text { information with } \\
\text { old information } \\
\text { by incorporating } \\
\text { historical as well } \\
\text { as new } \\
\text { information in } \\
\text { output, reducing } \\
\text { the need for } \\
\text { memory retrieval. }\end{array}$ & $\begin{array}{l}\text { How auditors overcome } \\
\text { the confirmation bias in } \\
\text { the context BD? } \\
\text { What strategies can be } \\
\text { developed by BDA to } \\
\text { support the processing of } \\
\text { both new and stored } \\
\text { information for quality } \\
\text { audit judgement? }\end{array}$ \\
\hline \multicolumn{3}{|l|}{ Order effect } \\
\hline $\begin{array}{l}\text { - Auditors exhibit recency bias by } \\
\text { constantly updating their beliefs } \\
\text { by incorporating recent } \\
\text { information. }\end{array}$ & $\begin{array}{l}\text { Big Data Analytics } \\
\text { can reduce the } \\
\text { auditor's ability to } \\
\text { exhibit recency } \\
\text { effect by } \\
\text { incorporating all } \\
\text { relevant } \\
\text { information in } \\
\text { data analytics } \\
\text { output. }\end{array}$ & $\begin{array}{l}\text { - How receny effect can } \\
\text { influence the auditor's } \\
\text { judgement in the context } \\
\text { of } \mathrm{BD} \text { analysis? }\end{array}$ \\
\hline
\end{tabular}

Note: Author findings, propositions and directions for future research based on systematic literature review

the effect of cognitive limitations. The auditors can carefully analyze comprehensive, organized, standardized, abstract BDA to form unbiased audit opinion. Future studies can investigate the research questions presented in table 3 by using both financial and non-financial data of companies and experimental methodology to understand the auditor's information processing and its effect on audit judgement under the influence of cognitive errors in the context of $\mathrm{BD}$ and BDA.

The evidence on the real-time application of BDA is very limited, however most of the existing studies have focused on the theoretical perspective of the uses, benefits and challenges of BD and BDA (e.g. Earley, 2015) or teaching material (i.e. case) on the application of BD and advanced analytics (e.g. Enget, Saucedo and Wright, 2015; McKinney, Yoos, and Snead, 2017). The current study aim was to present systematic literature by establishing the role of cognitive errors on associations between memory processes and judgement, not to provide meta-analysis based on existing studies because of the lack of empirical articles on the application of BDA. Similarly, there is also lack of real-time BDA examples. Therefore, current study only focused on systematic review and not provided any real-time examples of BDA application in auditing. Thus, future research can overcome the limitation of current literature review by providing evidence on the real-time application of BD and BDA or case-based studies to explore the application and benefits of using BD and BDA in audit judgement.

\section{Supplementary material}

\section{Conflicts of interest}

The authors have no conflicts of interest to declare.

Appendix $A$

List of titles selected in Web of Science query

1. ABACUS A JOURNAL OF ACCOUNTING FINANCE AND BUSINESS STUDIES

2. ACCOUNTING AND BUSINESS RESEARCH

3. JOURNAL OF ACCOUNTING AND ORGANIZATIONAL CHANGE

4. ACCOUNTING AND FINANCE

5. JOURNAL OF ACCOUNTING AND PUBLIC POLICY

6. ACCOUNTING AUDITING ACCOUNTABILITY JOURNAL

7. JOURNAL OF ACCOUNTING AUDITING AND FINANCE

8. ACCOUNTING HORIZONS

9. JOURNAL OF ACCOUNTING ECONOMICS

10. ACCOUNTING ORGANIZATIONS AND SOCIETY

11. JOURNAL OF ACCOUNTING IN EMERGING ECONOMIES

12. ACCOUNTING RESEARCH JOURNAL

13. JOURNAL OF ACCOUNTING RESEARCH

14. ACCOUNTING REVIEW

15. JOURNAL OF APPLIED ACCOUNTING RESEARCH

16. MANAGERIAL AUDITING JOURNAL

17. JOURNAL OF BEHAVIORAL AND EXPERIMENTAL FINANCE

18. MEDITARI ACCOUNTANCY RESEARCH

19. JOURNAL OF BEHAVIORAL FINANCE

20. ASIAN JOURNAL OF BUSINESS AND ACCOUNTING

21. JOURNAL OF BUSINESS FINANCE ACCOUNTING

22. ASIAN REVIEW OF ACCOUNTING

23. PACIFIC ACCOUNTING REVIEW

24. AUDITING A JOURNAL OF PRACTICE THEORY

25. CONTEMPORARY ACCOUNTING RESEARCH

26. CRITICAL PERSPECTIVES ON ACCOUNTING

27. QUALITATIVE RESEARCH IN ACCOUNTING AND MANAGEMENT

28. EUROPEAN ACCOUNTING REVIEW

29. JOURNAL OF FINANCIAL REPORTING AND ACCOUNTING 


\section{REVIEW OF ACCOUNTING AND FINANCE}

\section{REVIEW OF ACCOUNTING STUDIES}

32. REVIEW OF BEHAVIORAL FINANCE

\section{JOURNAL OF INFORMATION SYSTEMS}

34. INTERNATIONAL JOURNAL OF ACCOUNTING INFORMATION SYSTEMS

\section{REVIEW OF QUANTITATIVE FINANCE AND ACCOUNT-} ING

36. JOURNAL OF ISLAMIC ACCOUNTING AND BUSINESS RESEARCH

37. SUSTAINABILITY ACCOUNTING MANAGEMENT AND POLICY JOURNAL

\section{References}

Ahlawat, S. S. (1999). Order effects and memory for evidence in individual versus group decision making in auditing. Journal of Behavioral Decision Making, 12(1), 71.

Alles, M. (2015). The drivers of the adoption and facilitators of the evolution of Big Data by the audit profession. Accounting Horizons, 29(2), 439-449.

Alles, M. G., Kogan, A., \& Vasarhelyi, M. A. (2008). Putting continuous auditing theory into practice: Lessons from two pilot implementations. Journal of Information Systems, 22(2), 195-214.

Alles, M., \& Gray, G. L. (2016). Incorporating Big Data in audits: Identifying inhibitors and a research agenda to address those inhibitors. International Journal of Accounting Information Systems, 22, 44-59.

Alles, M., Brennan, G., Kogan, A., \& Vasarhelyi, M. A. (2006). Continuous monitoring of business process controls: A pilot implementation of a continuous auditing system at Siemens. International Journal of Accounting Information Systems, 7(2), 137-161.

Amer, T. S. (2005). Bias due to visual illusion in the graphical presentation of accounting information. Journal of Information Systems, 19(1), 1-18.

Anderson, J. C., Kaplan, S. E., \& Reckers, P. M. (1992). The effects of output interference on analytical procedures judgments. Auditing, 11(2), 1.

Appelbaum, D. A., Kogan, A., \& Vasarhelyi, M. A. (2018). Analytical procedures in external auditing: A comprehensive literature survey and framework for external audit analytics. Journal of Accounting Literature, 40, 83-101.

Appelbaum, D., Kogan, A., \& Vasarhelyi, M. A. (2017). Big Data and analytics in the modern audit engagement: Research needs. Auditing: A Journal of Practice \& Theory, 36(4), 1-27.

Arnold, V., Sutton, S. G., Hayne, S. C., \& Smith, C. A. (2000). Group decision making: The impact of opportunitycost time pressure and group support systems. Behavioral Research in Accounting, 12, 69.

Asare, S. K. (1992). The auditor's going-concern decision: Interaction of task variables and the sequential processing of evidence. Accounting Review, 379-393.

Ashton, A. H., \& Ashton, R. H. (1988). Sequential belief revision in auditing. Accounting Review, 623-641.

Ashton, R. H. (1974). Behavioral implications of information overload in managerial accounting reports. Cost and Management, 48(4), 37-40.

Ashton, R. H. (1990). Pressure and performance in accounting decision settings: Paradoxical effects of incentives, feedback, and justification. Journal of Accounting Research, 148-180.

Atkinson, R. C., \& Shiffrin, R. M. (1968). Human memory: A proposed system and its control processes. Psychology of learning and motivation, 2, 89-195.

Baddeley, A. D., \& Hitch, G. J. (1977). Recency reexamined. Attention and performance VI, 647-667.

Benbasat, I., \& Taylor, R. N. (1982). Behavioral aspects of information processing for the design of management information systems. IEEE Transactions on Systems, Man, and Cybernetics, 12(4), 439-450.

Bennett, G. B., \& Hatfield, R. C. (2017). Do Approaching Deadlines Influence Auditors' Materiality Assessments? Auditing: A Journal of Practice and Theory. 36 (4), 29-48.

Birnberg, J. G., \& Shields, M. D. (1984). The role of attention and memory in accounting decisions. Accounting, Organizations and Society, 9(3-4), 365-382.

Blay, A. D. (2005). Independence threats, litigation risk, and the auditor's decision process. Contemporary Accounting Research, 22(4), 759-789.

Bless, H. (2000). The interplay of affect and cognition: The mediating role of general knowledge structures. In J. P. Forgas (Ed.), Studies in emotion and social interaction, second series. Feeling and thinking: The role of affect in social cognition (pp. 201-222). New York: Cambridge University Press.

Bonner, S. E. (2008). Judgment and decision making in accounting. Prentice Hall.

Bower, G. H. (1992). How might emotions affect learning. The handbook of emotion and memory: Research and theory, 3, 31 .

Brainerd, C. J., \& Reyna, V. F. (2002). Fuzzy-trace theory and false memory. Current Directions in Psychological Science, 11(5), 164-169.

Braun, R. L. (2000). The effect of time pressure on auditor attention to qualitative aspects of misstatements indicative of potential fraudulent financial reporting. Accounting, Organizations and Society, 25(3), 243-259.

Brown-Liburd, H., Issa, H., \& Lombardi, D. (2015). Behavioral implications of Big Data's impact on audit judgment and decision making and future research directions. Accounting Horizons, 29(2), 451-468.

Bruner, J. S., \& Austin, G. A. (1986). A study of thinking. Transaction publishers.

Buchanan, J., \& Kock, N. (2001). Information overload: A decision making perspective. In Multiple Criteria Decision Making in the New Millennium (49-58). Springer, Berlin, Heidelberg.

Cao, M., Chychyla, R., \& Stewart, T. (2015). Big Data analytics in financial statement audits. Accounting Horizons, 29(2), 423-429.

Capriotti, R. J. (2014). Big Data Bringing Big Changes to Accounting. Pennsylvania CPA Journal, 85(2), 1-3.

Chang, C. J., Yen, S. H., \& Duh, R. R. (2002). An empirical examination of competing theories to explain the framing effect in accounting-related decisions. Behavioral Research in Accounting, 14(1), 35-64.

Chewning Jr, E. G., \& Harrell, A. M. (1990). The effect of information load on decision makers' cue utilization levels and decision quality in a financial distress decision task. Accounting, Organizations and Society, 15(6), 527-542.

Chewning, E. G., \& Harrell, A. M. (1990). The effect of information load on decision makers' cue utilization levels and decision quality in a financial distress decision task. Accounting, Organizations and Society, 15(6), 527-542.

Choo, F. (1995). Auditors' judgment performance under 
stress: A test of the predicted relationship by three theoretical models. Journal of Accounting, Auditing \& Finance, 10(3), 611-641.

Chung, J. O., Cohen, J. R., \& Monroe, G. S. (2008). The effect of moods on auditors' inventory valuation decisions. Auditing: A Journal of Practice \& Theory, 27(2), 137-159.

Cianci, A. M., \& Bierstaker, J. L. (2009). The impact of positive and negative mood on the hypothesis generation and ethical judgments of auditors. Auditing: A Journal of Practice \& Theory, 28(2), 119-144.

Clore, G. L., \& Huntsinger, J. R. (2007). How emotions inform judgment and regulate thought. Trends in Cognitive Sciences, 11(9), 393-399.

Courtis, J. K. (2004). Colour as visual rhetoric in financial reporting. Accounting Forum, 28 (3), 265-281.

Cowan, N. (2010). The magical mystery four: How is working memory capacity limited, and why?. Current Directions in Psychological Science, 19(1), 51-57.

Criss, A. H., Malmberg, K. J., \& Shiffrin, R. M. (2011). Output interference in recognition memory. Journal of Memory and Language, 64(4), 316-326.

Danner, U. N., Aarts, H., \& de Vries, N. K. (2007). Habit formation and multiple means to goal attainment: Repeated retrieval of target means causes inhibited access to competitors. Personality and Social Psychology Bulletin, 33(10), 1367-1379.

Ding, Y., Hellmann, A., \& De Mello, L. (2017). Factors driving memory fallibility: A conceptual framework for accounting and finance studies. Journal of Behavioral and Experimental Finance, 14, 14-22.

Dominique, J. F., Roozendaal, B., \& McGaugh, J. L. (1998). Stress and glucocorticoids impair retrieval of long-term spatial memory. Nature, 394(6695), 787-790.

Dowling, C., \& Leech, S. (2007). Audit support systems and decision aids: Current practice and opportunities for future research. International Journal of Accounting Information Systems, 8(2), 92-116.

Driver, M. J., \& Mock, T. J. (1975). Human information processing, decision style theory, and accounting information systems. Accounting Review, 50(3), 490-508.

Earley, C. E. (2015). Data analytics in auditing: Opportunities and challenges. Business Horizons, 58(5), 493-500.

Endler, N. S., \& Magnusson, D. (1976). Toward an interactional psychology of personality. Psychological bulletin, 83(5), 956.

Enget, K., Saucedo, G. D., \& Wright, N. S. (2017). Mystery, Inc.: A Big Data case. Journal of Accounting Education, 38, 9-22.

Estes, W. K. (1986). Array models for category learning. Cognitive psychology, 18(4), 500-549.

Fiske, S. T., \& Taylor, S. E. (2013). Social cognition: From brains to culture. Sage.

Forgas, J. P. (1995). Strange couples: Mood effects on judgments and memory about prototypical and atypical relationships. Personality and Social Psychology Bulletin, 21(7), 747-765.

Frederick, D. M. (1991). Auditors' representation and retrieval of internal control knowledge. Accounting Review, 240-258.

Gandomi, A., \& Haider, M. (2015). Beyond the hype: Big data concepts, methods, and analytics. International Journal of Information Management, 35(2), 137-144.

Gaudine, A., \& Thorne, L. (2001). Emotion and ethical decision-making in organizations. Journal of Business Ethics, 31(2), 175-187.

Gepp, A., Linnenluecke, M. K., O’Neill, T. J., \& Smith, T.
(2018). Big data techniques in auditing research and practice: Current trends and future opportunities. Journal of Accounting Literature, 40, 102-115.

Gibbins, M. (1984). Propositions about the psychology of professional judgment in public accounting. Journal of Accounting Research, 103-125.

Glover, S. M. (1997). The influence of time pressure and accountability on auditors' processing of nondiagnostic information. Journal of Accounting Research, 35(2), 213-226.

Green, W. (2008). Does repetition impair auditors' judgments?. Managerial Auditing Journal, 23(8), 724-743.

Grossman, A. M., \& Welker, R. B. (2011). Does the arrangement of audit evidence according to causal connections make auditors more susceptible to memory conjunction errors?. Behavioral Research in Accounting, 23(2), 93-115.

GuiralContreras, A., GonzaloAngulo, J. A., \& Rodgers, W. (2007). Information content and recency effect of the audit report in loan rating decisions. Accounting \& Finance, 47(2), 285-304.

Gul, F. A., Wu, D., \& Yang, Z. (2013). Do individual auditors affect audit quality? Evidence from archival data. Accounting Review, 88(6), 1993-2023.

Hackenbrack, K. (1992). Implications of seemingly irrelevant evidence in audit judgment. Journal of Accounting Research, 126-136.

Hastie, R., \& Dawes, R. M. (2010). Rational choice in an uncertain world: The psychology of judgment and decision making. Sage.

Hellmann, A. (2016). The role of accounting in behavioral finance. Journal of Behavioral and Experimental Finance, 9, 39-42.

Hellmann, A., Yeow, C., \& De Mello, L. (2017). The influence of textual presentation order and graphical presentation on the judgements of non-professional investors. Accounting and Business Research, 47(4), 455-470.

Henckens, M. J., Hermans, E. J., Pu, Z., Joëls, M., \& Fernández, G. (2009). Stressed memories: how acute stress affects memory formation in humans. Journal of Neuroscience, 29(32), 10111-10119.

Hilton, R. W. (1980). Integrating normative and descriptive theories of information processing. Journal of Accounting Research, 477-505.

Hirshleifer, D., \& Teoh, S. H. (2003). Limited attention, information disclosure, and financial reporting. Journal of Accounting and Economics, 36(1), 337-386.

Hoch, S. J. (1984). Availability and interference in predictive judgment. Journal of Experimental Psychology: Learning, Memory, and Cognition, 10(4), 649.

Hogarth, R. M., \& Einhorn, H. J. (1992). Order effects in belief updating: The belief-adjustment model. Cognitive Psychology, 24(1), 1-55.

Hsieh, H. F., \& Shannon, S. E. (2005). Three approaches to qualitative content analysis. Qualitative Health Research, 15(9), 1277-1288.

Huerta, E., \& Jensen, S. (2017). An accounting information systems perspective on data analytics and Big Data. Journal of Information Systems, 31(3), 101-114.

Iselin, E. R. (1988). The effects of information load and information diversity on decision quality in a structured decision task. Accounting, Organizations and Society, 13(2), 147-164.

Issa, H., \& Kogan, A. (2014). A predictive ordered logistic regression model as a tool for quality review of control risk assessments. Journal of Information Systems, 28(2), 209229.

Johansen, M. K., Savage, J., Fouquet, N., \& Shanks, D. R. 
(2015). Salience not status: How category labels influence feature inference. Cognitive Science, 39(7), 1594-1621.

Johnson, E. N. (1994). Auditor memory for audit evidence: Effects of group assistance, time delay, and memory task. Auditing, 13(1), 36.

Jonides, J., Lewis, R. L., Nee, D. E., Lustig, C. A., Berman, M. G., \& Moore, K. S. (2008). The Mind and Brain of ShortTerm Memory. Annual Review of Psychology, 59, 193-224.

Kachelmeier, S. J., \& Messier Jr, W. F. (1990). An investigation of the influence of a nonstatistical decision aid on auditor sample size decisions. Accounting Review, 209-226.

Kahneman, D. \& Tversky, A., (1979), "Prospect theory: An analysis of decision under risk". Econometrica: Journal of the Econometric Society, 263-291.

Kahneman, D. (2002). Maps of bounded rationality: A perspective on intuitive judgment and choice. Nobel Prize Lecture, 8, 351-401.

Kida, T., \& Smith, J. F. (1995). The encoding and retrieval of numerical data for decision making in accounting contexts: Model development. Accounting, Organizations and Society, 20(7-8), 585-610.

Kida, T., Smith, J. F., \& Maletta, M. (1998). The effects of encoded memory traces for numerical data on accounting decision making. Accounting, Organizations and Society, 23(5-6), 451-466.

Kiken, L. G., \& Fredrickson, B. L. (2017). Cognitive Aspects of Positive Emotions: A Broader View for Well-Being. In The Happy Mind: Cognitive Contributions to Well-Being (pp. 157-175). Springer, Cham.

Kleinmuntz, B. (1990). Why we still use our heads instead of formulas: Toward an integrative approach. Psychological bulletin, 107(3), 296.

Kogan, A., Alles, M. G., Vasarhelyi, M. A., \& Wu, J. (2014). Design and evaluation of a continuous data level auditing system. Auditing: A Journal of Practice \& Theory, 33(4), 221245.

Kokina, J., \& Davenport, T. H. (2017). The emergence of artificial intelligence: How automation is changing auditing. Journal of Emerging Technologies in Accounting, 14(1), 115122.

Kopp, L. S., \& Bierstaker, J. L. (2006). Auditors' memory of internal control information: the effect of documentation preparation versus review. Advances in Accounting Behavioral Research, 9, 27-50.

Kruschke, J. K., \& Johansen, M. K. (1999). A model of probabilistic category learning. Journal of Experimental Psychology-Learning Memory and Cognition, 25(5), 10831119.

Kuhlmann, S., Piel, M., \& Wolf, O. T. (2005). Impaired memory retrieval after psychosocial stress in healthy young men. Journal of Neuroscience, 25(11), 2977-2982.

Labrinidis, A., \& Jagadish, H. V. (2012). Challenges and opportunities with big data. Proceedings of the VLDB Endowment, 5(12), 2032-2033.

Lampinen, J. M., Watkins, K. N., \& Odegard, T. N. (2006). Phantom ROC: Recollection rejection in a hybrid conjoint recognition signal detection model. Memory, 14(6), 655-671.

Lerner, J. S., Li, Y., Valdesolo, P., \& Kassam, K. S. (2015). Emotion and decision making. Annual Review of Psychology, 66.

Libby, R. (1985). Availability and the generation of hypotheses in analytical review. Journal of Accounting Research, 648-667.

Libby, R., \& Trotman, K. T. (1993). The review process as a control for differential recall of evidence in auditor judg- ments. Accounting, Organizations and Society, 18(6), 559574.

Libby, R., Bloomfield, R., \& Nelson, M. W. (2002). Experimental research in financial accounting. Accounting, Organizations and Society, 27(8), 775-810.

Lowe, D. J., \& Reckers, P. M. (1997). The influence of outcome effects, decision aid usage, and intolerance of ambiguity on evaluations of professional audit judgement. International Journal of Auditing, 1(1), 43-58.

Mac Donald Jr, A. P. (1970). Revised scale for ambiguity tolerance: Reliability and validity. Psychological Reports, 26(3), 791-798.

Maines, L. A. (1995). Judgment and decision-making research in financial accounting: A review and analysis. Judgment and decision-making research in accounting and auditing, 76-101.

Manyika, J., Chui, M., Brown, B., Bughin, J., Dobbs, R., Roxburgh, C., \& Byers, A. H. (2016). Big Data: The next frontier for innovation, competition, and productivity. A report by the McKinsey Global Institute, May 2011.

McKinney Jr, E., Yoos II, C. J., \& Snead, K. (2017). The need for 'skeptical'accountants in the era of Big Data. Journal of Accounting Education, 38, 63-80.

Messier Jr, W. F., Kachelmeier, S. J., \& Jensen, K. L. (2001). An experimental assessment of recent professional developments in nonstatistical audit sampling guidance. Auditing: A Journal of Practice \& Theory, 20(1), 81-96.

Miller, D., \& Gordon, L. A. (1975). Conceptual levels and the design of accounting information systems. Decision Sciences, 6(2), 259-269.

Mock, T. J., \& Vasarhelyi, M. A. (1978). A synthesis of the information economics and lens models. Journal of Accounting Research, 414-423.

Moeckel, R. (1990). On central configurations. Mathematische Zeitschrift, 205(1), 499-517.

Moffitt, K. C., \& Vasarhelyi, M. A. (2013). AIS in an age of Big Data. Journal of Information Systems, 27(2), 1-19.

Moher, D., Shamseer, L., Clarke, M., Ghersi, D., Liberati, A., Petticrew, M., ... \& Stewart, L. A. (2015). Preferred reporting items for systematic review and meta-analysis protocols (PRISMA-P) 2015 statement. Systematic Reviews, 4(1), 1.

Morrill, J. B., Morrill, C. K., \& Kopp, L. S. (2011). Internal control assessment and interference effects. Behavioral Research in Accounting, 24(1), 73-90.

Moser, D. V. (1989). The effects of output interference, availability, and accounting information on investors' predictive judgments. Accounting Review, 433-448.

Neath, I., \& Nairne, J. S. (1995). Word-length effects in immediate memory: Overwriting trace decay theory. Psychonomic Bulletin \& Review, 2(4), 429-441.

Nelson, M., \& Tan, H. T. (2005). Judgment and decision making research in auditing: A task, person, and interpersonal interaction perspective. Auditing: A Journal of Practice \& Theory, 24(s-1), 41-71.

Nisbett, R. E., Zukier, H., \& Lemley, R. E. (1981). The dilution effect: Nondiagnostic information weakens the implications of diagnostic information. Cognitive Psychology, 13(2), 248-277.

Norton, R. W. (1975). Measurement of ambiguity tolerance. Journal of Personality Assessment, 39(6), 607-619.

Pincus, K. V. (1989). The efficacy of a red flags questionnaire for assessing the possibility of fraud. Accounting, Organizations and Society, 14(1-2), 153-163.

Reyna, V. F., \& Brainerd, C. J. (1995). Fuzzy-trace theory: An interim synthesis. Learning and Individual Differences, 
7(1), 1-75

Ricciardi, V. (2008). The psychology of risk: The behavioral finance perspective. Handbook of finance.

Roediger III, H. L., \& Karpicke, J. D. (2006). The power of testing memory: Basic research and implications for educational practice. Perspectives on Psychological Science, 1(3), 181-210.

Roediger, H. L., \& Thorpe, L. A. (1978). The role of recall time in producing hypermnesia. Memory \& Cognition, 6(3), 296-305.

Ruchkin, D. S., Grafman, J., Cameron, K., \& Berndt, R. S. (2003). Working memory retention systems: A state of activated long-term memory. Behavioral and Brain Sciences, 26(6), 709-728.

Schacter, D. L. (1999). The seven sins of memory: Insights from psychology and cognitive neuroscience. American Psychologist, 54(3), 182.

Schick, A. G., Gordon, L. A., \& Haka, S. (1990). Information overload: A temporal approach. Accounting, Organizations and Society, 15(3), 199-220.

Schneider, G. P., Dai, J., Janvrin, D. J., Ajayi, K., \& Raschke, R. L. (2015). Infer, predict, and assure: Accounting opportunities in data analytics. Accounting Horizons, 29(3), 719-742.

Simnett, R. (1996). The effect of information selection, information processing and task complexity on predictive accuracy of auditors. Accounting, Organizations and Society, 21(7-8), 699-719.

Simon, H. A. (1978). Rationality as process and as product of thought. American Economic Review, 1-16.

Smith, J. F., \& Kida, T. (1991). Heuristics and biases: Expertise and task realism in auditing. Psychological bulletin, 109(3), 472.

So, S., \& Smith, M. (2002). Colour graphics and task complexity in multivariate decision making. Accounting, Auditing \& Accountability Journal, 15(4), 565-593.

Spilker, B. C., \& Prawitt, D. F. (1997). Adaptive responses to time pressure: The effects of experience on tax information search behavior. Behavioral Research in Accounting, 9, 172-198.

Stahlberg, D., \& Maass, A. (1997). Hindsight bias: Impaired memory or biased reconstruction?. European Review of Social Psychology, 8(1), 105-132.

Stocks, M. H., \& Harrell, A. (1995). The impact of an increase in accounting information level on the judgment quality of individuals and groups. Accounting, Organizations and Society, 20(7-8), 685-700.

Theis, J. C., Yankova, K., \& Eulerich, M. (2012). Information order effects in the context of management commentary-initial experimental evidence. Journal of Management Control, 23(2), 133-150.

Tomlinson, T. D., Huber, D. E., Rieth, C. A., \& Davelaar, E. J. (2009). An interference account of cue-independent forgetting in the no-think paradigm. Proceedings of the National Academy of Sciences, 106(37), 15588-15593.

Tonoki, A., \& Davis, R. L. (2012). Aging impairs intermediate-term behavioral memory by disrupting the dorsal paired medial neuron memory trace. Proceedings of the National Academy of Sciences, 109(16), 6319-6324.

Tractinsky, N., \& Meyer, J. (1999). Chartjunk or goldgraph? Effects of presentation objectives and content desirability on information presentation. MIS Quarterly, 397-420.

Tubbs, R. M., Messier Jr, W. F., \& Knechel, W. R. (1990). Recency effects in the auditor's belief-revision process. Accounting Review, 452-460.

Tversky, A., \& Kahneman, D. (1973). Availability: A heur- istic for judging frequency and probability. Cognitive Psychology, 5(2), 207-232.

Wadlinger, H. A., \& Isaacowitz, D. M. (2006). Positive mood broadens visual attention to positive stimuli. Motivation and Emotion, 30(1), 87-99.

Weber, E. U., \& Johnson, E. J. (2009). Mindful judgment and decision making. Annual Review of Psychology, 60, 5385.

Weick, K. E. (1983). Stress in accounting systems. Accounting Review, 58(2), 350-369.

Whitecotton, S. M. (1996). The effects of experience and a decision aid on the slope, scatter, and bias of earnings forecasts. Organizational Behavior and Human Decision Processes, 66(1), 111-121.

Wright, W. F., \& Bower, G. H. (1992). Mood effects on subjective probability assessment. Organizational Behavior and Human Decision Processes, 52(2), 276-291.

Zhang, J., Yang, X., \& Appelbaum, D. (2015). Toward effective Big Data analysis in continuous auditing. Accounting Horizons, 29(2), 469-476. 